\title{
Identification of novel genes in the carotenogenic and oleaginous yeast Rhodotorula toruloides through genome- wide insertional mutagenesis
}

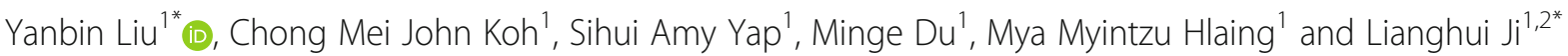

\begin{abstract}
Background: Rhodotorula toruloides is an outstanding producer of lipids and carotenoids. Currently, information on the key metabolic pathways and their molecular basis of regulation remains scarce, severely limiting efforts to engineer it as an industrial host.

Results: We have adapted Agrobacterium tumefaciens-mediated transformation (ATMT) as a gene-tagging tool for the identification of novel genes in $R$. toruloides. Multiple factors affecting transformation efficiency in several species in the Pucciniomycotina subphylum were optimized. The Agrobacterium transfer DNA (T-DNA) showed predominantly singlecopy chromosomal integrations in $R$. toruloides, which were trackable by high efficiency thermal asymmetric interlaced PCR (hiTAIL-PCR). To demonstrate the application of random T-DNA insertions for strain improvement and gene hunting, 3 T-DNA insertional libraries were screened against cerulenin, nile red and tetrazolium violet respectively, resulting in the identification of 22 mutants with obvious phenotypes in fatty acid or lipid metabolism. Similarly, 5 carotenoid biosynthetic mutants were obtained through visual screening of the transformants. To further validate the gene tagging strategy, one of the carotenoid production mutants, RAM5, was analyzed in detail. The mutant had a T-DNA inserted at the putative phytoene desaturase gene CAR1. Deletion of CAR1 by homologous recombination led to a phenotype similar to RAM5 and it could be genetically complemented by re-introduction of the wild-type CAR1 genome sequence.
\end{abstract}

Conclusions: T-DNA insertional mutagenesis is an efficient forward genetic tool for gene discovery in $R$. toruloides and related oleaginous yeast species. It is also valuable for metabolic engineering in these hosts. Further analysis of the 27 mutants identified in this study should augment our knowledge of the lipid and carotenoid biosynthesis, which may be exploited for oil and isoprenoid metabolic engineering.

Keywords: Agrobacterium tumefaciens-mediated transformation, Pucciniomycotina, Insertional mutagenesis, Metabolic engineering, Carotenoid and lipid biosynthesis

\section{Background}

A large number of oleaginous microorganisms capable of producing more than $20 \%$ of their dry biomass as lipids have been reported to date [1-3]. They are potential alternative hosts to plants for the production of lipid and fatty acid derivatives, such as biodiesel, alkane, fatty alcohol and wax $[1,4-7]$. On the other hand, only limited number

\footnotetext{
* Correspondence: yanbin@tll.org.sg; jilh@tll.org.sg

${ }^{1}$ Biomaterials and Biocatalysts Group, Temasek Life Sciences Laboratory, 1 Research Link, National University of Singapore, Singapore 117604, Singapore

Full list of author information is available at the end of the article
}

of non-photosynthetic microorganisms can naturally produce carotenoids, which are protective agents against UV radiation and oxidative stress (for review, see [8]). Rhodotorula toruloides (syn. Rhodosporidium toruloides [9]), a species of the Pucciniomycotina subphylum, has gained increasing attention due to its outstanding cell growth rate in high-density fermentation, high lipid and carotenoid productivity, and the capability to utilize cheap feedstocks [10-15].

Genetic tools for $R$. toruloides have increased steadily over recent years since the first report of stable genetic 
transformation [16]. R. toruloides is being developed as a new synthetic biology platform [16-26]. To date, information regarding the molecular control of metabolism and catabolism remains rare in this host, severely limiting the development of $R$. toruloides as an industrial workhorse.

Microbial adaptive laboratory evolution (ALE) is a useful tool for metabolic engineering [27]. Chemical mutagens and ultraviolet radiation are often used to improve strains or populations of interests under a specific selection pressure. Such techniques usually produce mutants with point mutations. Despite the technological advancement of genome sequencing technology, the identification of point mutations remains a tedious task [28, 29]. DNA insertional mutagenesis (IM) has become a versatile forward genetic tool in diverse species, including plants [30], animals [31, 32], algae [33], bacteria [34] and fungi [35]. Due to the high efficiency in generating genetic diversity, IM could be exploited for fast strain improvement, particularly for microbes [36]. Generally, a good gene tagging tool should have the following features: i). DNA is randomly integrated into the nuclear genome [35]; ii). disrupted gene targets can be easily identified [37, 38]; iii). the host contains a haploid genome [39-41]. Agrobacterium tumefaciens-mediated transformation (ATMT) delivers the T-DNA into the host's nuclear genome and has been widely used as an IM tool, particularly in fungi and plants [42-44].

Here, we demonstrate the application of ATMT for gene discovery and modifications of the metabolic pathway in R. toruloides.

\section{Results}

Application of ATMT in Puicciniomycotina subphylum

We have reported a reliable transformation protocol for $R$. toruloides ATCC 10657 (Rt1) using the dominant selection conferred by the codon-optimized hygromycin resistance gene (hygromycin-B-phosphotransferase gene $h p t-3)$ [16]. While the method was generally applicable in several species or strains in Pucciniomycotina, e.g. R. toruloides ATCC 10788 (Rt2), R. glutinis ATCC 90781 (Rg1), R. glutinis ATCC 204091 (Rg2), $R$. graminis WP1 (Rg3), and Sporobolomyces roseus FGSC 10293 (IAM13481, Sr) (Fig. 1a), large variations in the transformation efficiency (TFE, or Colony Forming Unit per $10^{6}$ fungal cells), were observed (Fig. 1b). The average of CFU for Rg3, Rg1, Rt2 and Sr was 985, 409, 227 and 197, respectively (Fig. 1b). Notably, strains Rt1 and Rg2 showed much lower TFE, producing only 18 and $10 \mathrm{CFU}$, respectively (Fig. 1b). Colony PCR (data not shown) and Southern blot analysis confirmed that more than $90 \%$ transformants contained an integrated T-DNA (Fig. 3; Data on Sr and Rg3 are not shown).
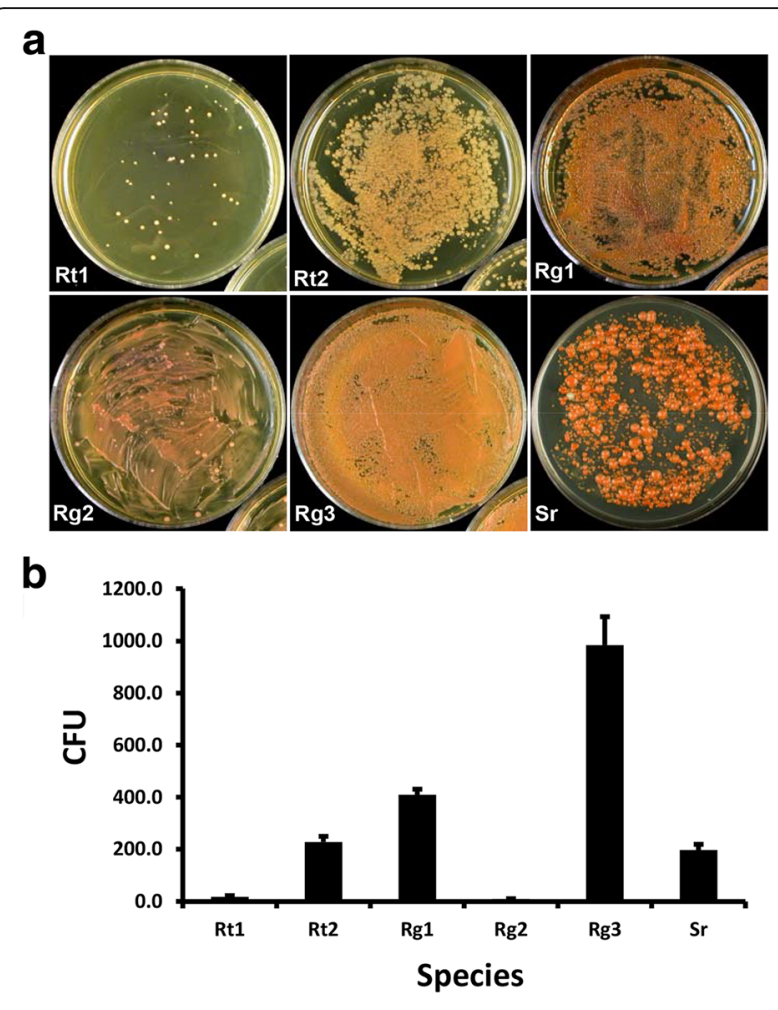

Fig. 1 ATMT in Pucciniomycotina species. a ATMT without the use of membrane support. b Transformation efficiency (TFE). Agrobacterium culture harboring binary vector $\mathrm{pRH} 201$ [16] was used as the donor in all trials. TFE was represented as CFU, colony forming unit per $10^{6}$ transformed fungal cells. Abbreviations of species: Rt1, R. toruloides ATCC 10657; Rt2, R. toruloides ATCC 10788; Rg1, R. glutinis ATCC 90781; Rg2, R. glutinis ATCC 204091; Rg3, R. graminis WP1; Sr, S. roseus

\section{Optimization of ATMT protocol for large-scale screening}

The low TFE for some strains prompted us to investigate the effects of various co-culture parameters. Similar to other reports, virulence inducer (acetosyringone) for agrobacteria, co-culture time, cell ratio between T-DNA recipient and donor, and promoters used to drive $h p t-3$ expression drastically influenced the TFE in $R$. toruloides (Additional file 1: Figure S1A-D). Notably, TFE was highly sensitive to the $\mathrm{pH}$ of the induction medium (Fig. 2a), where even a slight increase of $\mathrm{pH}$ from the optimum $(\mathrm{pH}$ 5.5) resulted in a dramatic decrease in TFE (Fig. 2a). The hardness of co-culture medium (agar concentration) also influenced TFE, with the optimal agar concentration observed at $2.0 \%(w / v)$ (Fig. 2b). The role of nitrogen concentration on TFE was investigated due to its multiple effects on energy metabolism, cell growth and differentiation $[45,46]$. In our standard ATMT protocol, $0.5 \mathrm{~g} / \mathrm{L}$ ammonium sulfate was used as the sole nitrogen source in the induction medium [16]. Increasing the concentration of ammonium sulfate led to severe reduction in TFE, and transformation was completely abolished at a level of $50 \mathrm{~g} / \mathrm{L}$ (Fig. 2c). 

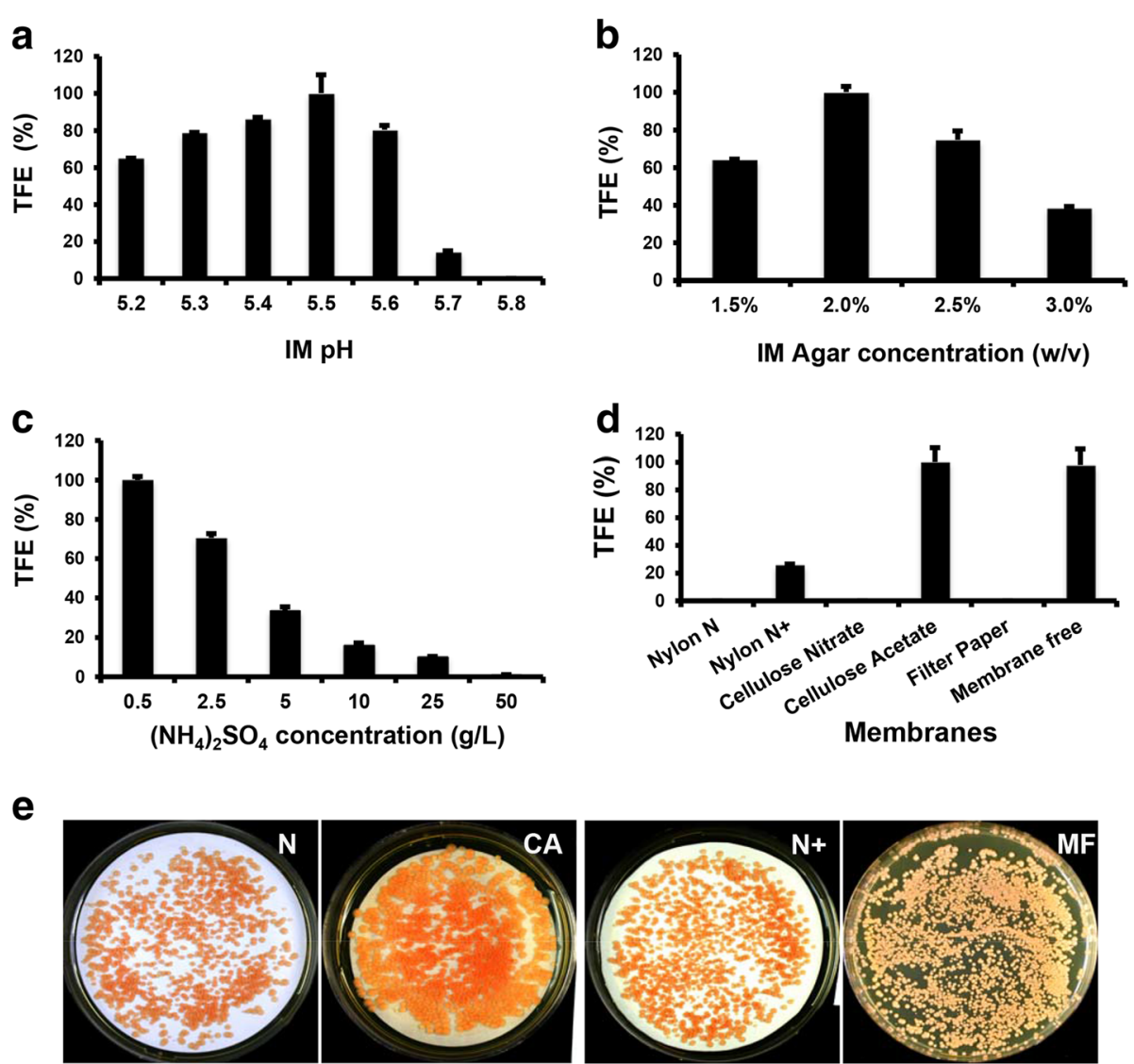

Fig. 2 Factors affecting transformation efficiency. a pH of induction medium (IM). IM pH was adjusted with 1.0 M hydrogen chloride. b Agar concentration of IM. c Ammonium sulfate concentration in IM. d Different membrane types. e Representative transformation on selected membranes. Membrane-free: transformation conducted without supporting membrane. R. toruloides ATCC 10657 was used as the T-DNA recipient. TFE is presented as the relative transformation efficiency, where the highest value under each tested condition was set to $100 \%$. Each condition was analyzed in triplicates. Error bars represent standard derivations. The induction medium was pH 5.5. Abbreviations of membranes: N, Nylon Hybond N membrane; CA, Cellulose acetate membrane; $\mathrm{N}^{+}$, Nylon Hybond $\mathrm{N}^{+}$membrane; MF, membrane-free

Furthermore, the effects of membrane types on TFE were investigated. Results showed that the different supporting membranes dramatically affected TFE, where the positively charged (nylon Hybond $\mathrm{N}^{+}$) and neutral membrane (cellulose acetate) supported higher TFE. Interestingly, co-culturing cells directly on the surface of agar medium (without the support of any membrane, membrane-free) led to a high TFE, comparable to that with cellulose acetate membrane (Fig. 2d).

\section{Characterization of genome-wide T-DNA insertion patterns}

Southern blot analysis of 64 T-DNA mutants from $R$. toruloides ATCC 10657 showed that 75\% of transformants contained a single copy of T-DNA, 20\% contained two copies, and the rest $5 \%$ contained three copies or more (Fig. 3). The average copy number of T-DNA in the genome was 1.36 .

The genome sequences adjacent to T-DNA tagging positions were analyzed by high efficiency thermal asymmetric interlaced PCR (hiTAIL PCR) [37, 38]. A total of
480 samples were analyzed, including 192 transformants of $R$. toruloides ATCC 10657 analyzed for both left border (LB) and right border (RB) flanking sequences, and 96 transformants of $R$. glutinis ATCC 90781 for LB flanking sequences only. The success rate of HiTAIL PCR was $72.5 \%$ (346/480), which yielded 268 high-quality sequencing results (77.5\%). To identify the chromosomal positions of T-DNA insertions, 61 LB flanking sequences were analyzed by BLASTn searches against the R. glutinis ATCC 204091 genome database (Additional file 2: Table S1). As expected, T-DNAs were mapped to the majority of scaffolds (21 out of 29), in which scaffold No. 2, 13, 18 and 26 showed the highest number of hits (Fig. 4a). Scaffolds that missed the analysis were all small in size.

T-DNA integration is known to be initiated at the RB, with DNA nicks generated between the 3rd and 4th nucleotide of the $25 \mathrm{bp}$ border repeat sequence (RB canonical insertion). Generally, deletions of various lengths are generated in the RB region of inserted T-DNAs [47]. Our results showed that T-DNA integration exhibited 


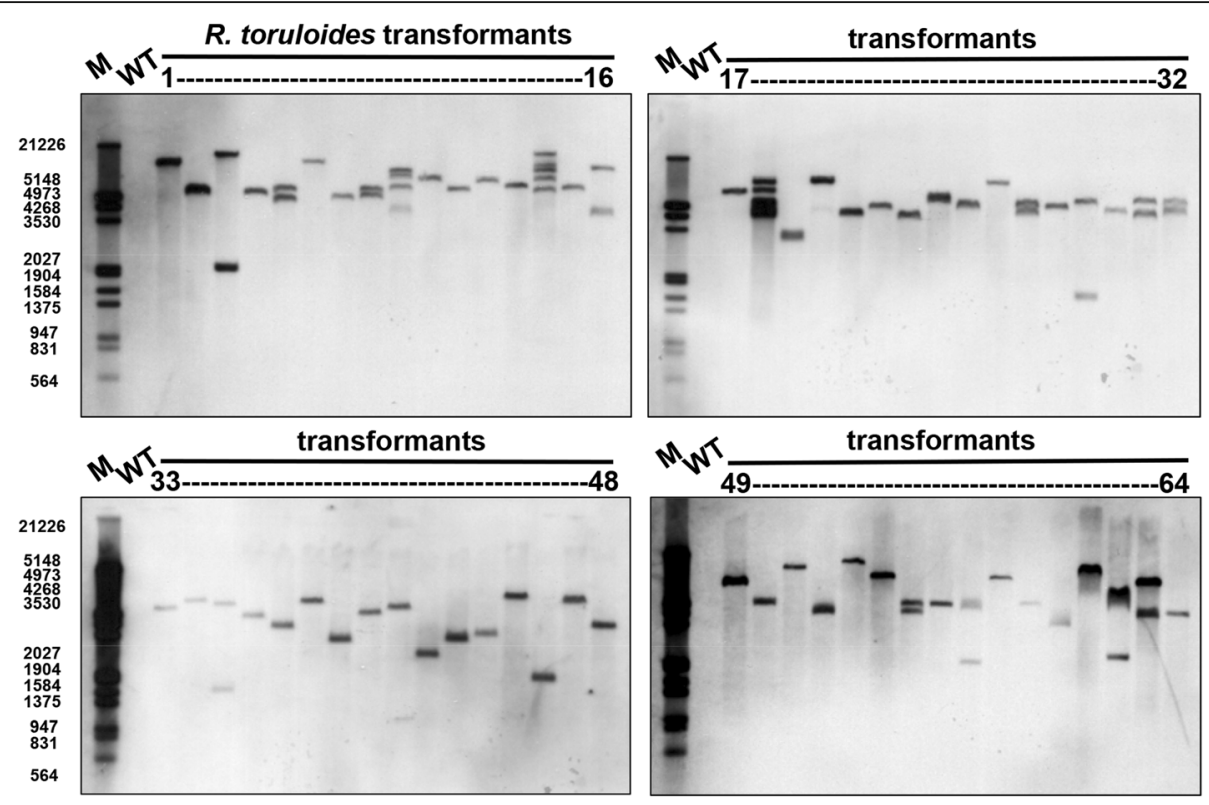

Fig. 3 Southern blot analysis of $R$. toruloides transformants. Genomic DNA samples of 64 randomly selected transformants of pRH201 and wild-type strain $R$. toruloides ATCC $10657(5 \mu \mathrm{g})$ were digested with Pstl and separated by electrophoresis in 0.8\% agarose gel. The 581 bp DNA fragment of partial hpt-3 gene amplified using oligos HptRU and HptRSL2 was used as the probe (Additional file 5: Table S3). Lane M, DIG-labeled DNA molecular size marker III (Roche Diagnosis, USA). Fragment sizes (bp): 564, 831, 947, 1375, 1584, 1904, 2027, 3530, 4268, 4973, 5148 and 21,226. WT: wild-type strain ATCC 10657

much higher accuracy at RB than LB (Fig. 4b), with $30.8 \%$ (79 of 172) of the inserted T-DNAs containing deletions (ranging from 1 to $80 \mathrm{bp}$ ) at RB end compared with $79.1 \%$ deletions (68 of 86$)$ at the LB end.

Microhomology at the insertion junctions was also examined. $73.7 \%$ (101 of 137) of LB insertions showed homology of 4 bp or more, compared with $42.0 \%$ (55 of 131) at RB. Microhomology of up to $10 \mathrm{bp}$ was found although it was usually less than 4 bp (Fig. 4c). Collectively, T-DNA integration in Rhodotorula species does not require long stretch of sequence homology at the cross-over position. This is similar to the illegitimate recombination reports in other species, such as budding yeast Saccharomyces cerevisiae [48], corn smut fungi Ustilago maydis [39], rice blast fungi Magnaporthe oryzae [49], plants [50] and mammals [51].

The DNA sequences within $1.0 \mathrm{~kb}$ from the insertion sites were annotated. As shown in Additional file 3: Table S2, most mutants could be functionally assigned: $15.8 \%$ are likely to be involved in glucan metabolism, $14.3 \%$ in transcription, $7.1 \%$ in protein folding and trafficking, $4.1 \%$ in carbohydrate metabolism, $4.1 \%$ in DNA replication and repair, and $4.1 \%$ in transport (Fig. 4d). The rest of the mutants $(26.0 \%)$ could not be functionally assigned (presented as "Unknown" in Fig. 4d). It was obvious that TDNA insertions had a strong bias towards gene coding and regulatory regions (Table 1 and Additional file 3: Table S2). Taken together, T-DNA insertions could be exploited to tag a wide range of genes.

\section{Direct identification of lipogenic mutants}

Cerulenin, (2S)(3R)2,3-epoxy-4-oxo-7,10-dodecadienoylamide, was discovered from the culture broth of Cephalosporium caerulens $[52,53]$. It has been used as a fungicide due to the inhibition effects on the biosynthesis of fatty acids and steroids [54]. Mutants that survive cerulenin treatment are expected to produce higher levels of lipid or polyunsaturated fatty acids (PUFAs), and the relevant genes would be useful for lipid metabolic engineering [55-57]. Approximately 10,000 transformants were screened against $50 \mu \mathrm{g} / \mathrm{mL}$ cerulenin in the selection plates, a level that fully blocked the growth of wild-type (WT) cells (Additional file 4: Figure S2A). A total of 12 T-DNA tagged strains that suvvived the treatment were collected and termed as Rhodotorula Cerulenin Mutants, RCM1 to RCM12. Notably, the average $\alpha$-linolenic acid (ALA, C18:3 $\Delta^{9,12,15}$ ) level, an omega-3 PUFA naturally produced in $R$. toruloides, was significantly improved in the 12-member mutant population (Fig. 6a). In particular, RCM6 produced $\sim 3$ folds higher level of ALA than WT (Fig. 6a).

Secondly, Nile red, a fluorescent dye used extensively for intracellular lipid tracking [58] and rapid estimation of intracellular lipid content [59], was tested as a selection marker. A T-DNA mutant library with $\sim 10,000$ transformants was selected on nile red-containing YPD agar plates. Visual examination under a fluorescent dissecting microscope (Additional file 4: Figure S2B) yielded 4 mutants exhibiting stronger fluorescence intensities. The mutants were named Rhodotorula Nile red Mutants, RNM1 to 

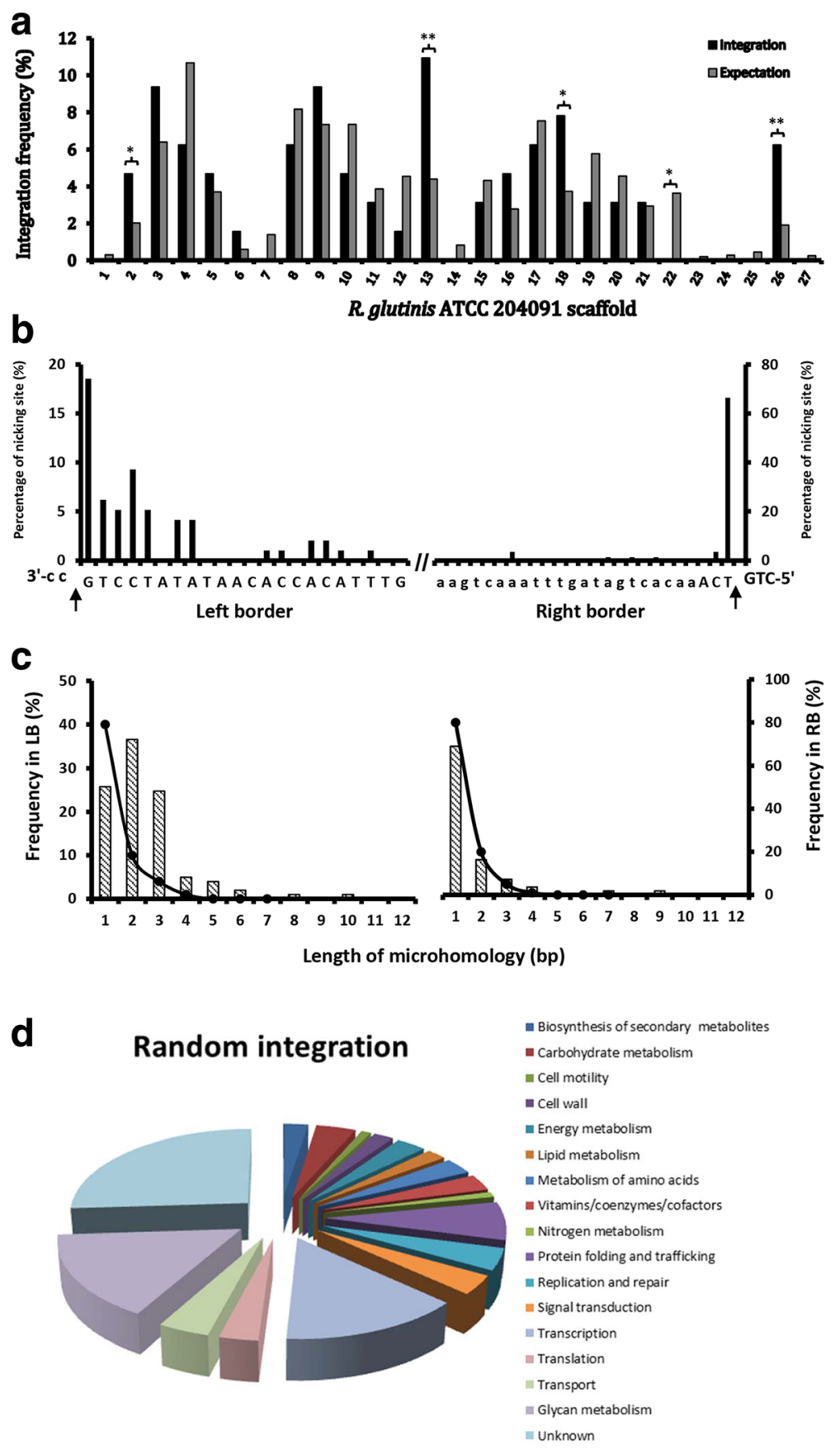

Fig. 4 Identification of T-DNA tagging sites. a Genomic distribution of T-DNAs. hiTAlL PCR product sequences were searched against the genome database of $R$. glutinis ATCC 204091. b Nicking positions of the integrated T-DNAs. Histogram of nicking sites were presented based on the nicking frequency calculated from 61 LB and 196 RB flanking sequences. T-DNA border repeats were capitalized. Arrows indicate the positions of T-DNA nicking by Agrobacterium. c Size distribution of microhomology. Columns show the distribution of microhomology sizes found in this study. Black line indicated the expected sizes of microhomology based on calculation. $\mathbf{d}$ Classification of proteins affected by the 132 T-DNA tags

RNM4. RNMs had significantly higher lipid contents than WT although they showed little differences in fatty acid profiles (Fig. 6b). Interestingly, RNM1 had its T-DNA inserted into the 3' UTR region of a putative omega-3 fatty acid desaturase gene (Table 2), resulting in a $47 \%$ increase in lipid accumulation (Fig. 6b).
Thirdly, tetrazolium violet, a redox indicator that gives colonies a distinct violet color if the cells accumulate lipids $[60,61]$, was tested as a selection marker for lipogenic mutants. As expected, supplementation of $10 \mu \mathrm{g} / \mathrm{mL}$ of tetrazolium violet in selection medium resulted in pigmented transformants (Additional file 4: Figure S2C). Screening 
Table 1 Distrubution of T-DNA insertion positions

\begin{tabular}{lll}
\hline Locations & Tagged loci & Percentage (\%) \\
\hline Upstream 0.5-1.0 kb & 13 & 10.7 \\
Upstream $0.5 \mathrm{~kb}$ & 18 & 14.9 \\
Downstream $0.3 \mathrm{~kb}$ & 5 & 4.1 \\
Coding sequence & 75 & 62.0 \\
Intergenic sequence & 10 & 8.3 \\
Total & 121 & 100.0 \\
\hline
\end{tabular}

of $\sim 3000$ transformants yielded 6 mutants with deeper pigmentation. The strains were named Rhodotorula Tetrazolium violet Mutants, RTM1 to RTM6. Again, RTMs had higher lipid content than WT (Fig. 6c), with little changes in the fatty acid compositions (data not shown).

The T-DNA insertion sites of above 22 mutants were analyzed by hiTAIL PCR, and 19 T-DNA flanking sequences were successfully identified (Table 2). The distribution of T-DNA insertion sites appeared similar to previous results (Table 1), where the T-DNAs were integrated in gene coding regions or regulatory regions within $1.0 \mathrm{~kb}$ upstream to the $0.3 \mathrm{~kb}$ downstream of the coding sequence (Table 2). The affected gene products of RCMs showed high correlation with the lipogenic bioprocess (Table 2). Similarily, the affected gene products of RNMs and RTMs were predicted to be involved in the metabolism of lipids (RNM1, RTM5), amino acids (RNM3), energy (RTM2), signal transduction (RTM1) and transcription (RTM3, 4 and 6).

\section{Direct identification of carotenoid production mutants}

To discover novel genes that are involved in the regulation of carotenoid biosynthesis, we designed a simple screening strategy based on the changes of colony color (Fig. 5b). From a population of $\sim 20,000$ T-DNA tagged mutants, 1 yellowish and 4 albino transformants were found and named Rhodotorula Albino Mutants, RAM1 to RAM5 (Fig. 7a and Additional file 4: Figure S2D). Sequence analysis revealed that T-DNA was inserted into the DNA sequence encoding a putative riboflavin transporter, resolvase, hexose transporter, TATA-binding protein associated factor and phytoene desaturase, respectively (Table 2). These data suggest that new factors for carotenoid biosynthesis could be identified through the IM approach.

\section{Validation of RAM5}

To validate the gene tagging strategies used, the albino mutant RAM5 was analyzed in detail (Fig. 7a). BLAST search of the hiTAIL PCR product showed that the T-DNA was inserted between nucleotide 391,802 and 391,803 in scaffold No.18 (AEVR02000018), disrupting the putative phytoene desaturase gene (CAR1, genome locus RTG_00274) at the 3rd exon. To validate the result,
CAR1 was deleted in WT through homologous recombination, which led to the replacement of the genome sequence between +948 and +2097 (from the translational start of CAR1) by the hygromycin resistance gene cassette $\left(\mathrm{P}_{G P D 1}::\right.$ hpt-3::Tnos, Fig. $\left.7 \mathrm{~b}\right)$. Indeed, the resulting car $1 \Delta$ mutant, which was confirmed by Southern blot analysis (Fig. 7c), showed similar creamy color as the T-DNA tagged mutant, RAM5 (Fig. 7d). Furthermore, re-introduction of the wild-type CAR1 sequence ( -662 to +2928 , Fig. 7b) into the genome of car1 $\Delta$ (the resulting mutant car1C) fully restored the cell color (Fig. 7d). HPLC analysis of carotenoids showed that the main carotenoid species produced in WT $R$. toruloides, such as torulene, torularhodin, $\gamma$-carotene and $\beta$-carotene [62-64], were totally absent in car1 $\Delta$, and fully restored in carlC (Fig. 7e and f). qRT-PCR analysis confirmed that the transcripts of CAR1 were undetectable in car1 $1 \triangle$ and restored in carlC (Fig. 7g). These data confirmed that CAR1 encodes a key enzyme in carotenoid biosynthesis. Thus, the successful identification of CAR1 further demonstrates that gene identification and strain improvement strategy based on T-DNA insertional mutagenesis is effective and reliable.

\section{Discussion}

$R$. toruloides is an unusual yeast species with highly efficient oil and carotenoid production capacity. However, its potential as an industrial host remains largely unexploited, in part because of the lag in the development of genetic tools. In this study, we report comprehensive studies on factors affecting ATMT efficiency. The data complements our previous report on the transformation method for this yeast [16]. To our surprise, some conditions such as the choice of membrane, $\mathrm{pH}$ value and agar concentration used for co-culture, were critical for the TFE. Even a minor change of the co-culture $\mathrm{pH}$ could be fatal for transformation (Fig. 2a). Therefore, it is advisable to optimize medium $\mathrm{pH}$, co-culture time and donor/recipient ratio when a new strain or taxa of yeast is used for ATMT. As the Umgpd::hpt-3 selection cassette has also been used successfully in the transformation of $U$. maydis and $U$. scitaminea $[16,65]$, it should be broadly useful for dominant selection in both Ustilaginomycotina and Puicciniomycotina subphyla.

In addition, it was feasible to perform ATMT without the use of supporting membrane for co-culture. The transformed cells could be transferred to selection plates by spreading (as was used herein), "wash and plate", replica printing or medium over-lay. Avoiding the use of membranes could also be appealing to researchers in under-developed countries.

Four screening strategies have been tested for direct identification of genes of interest, each with a specific focus. It is encouraging that mutants could be identified 


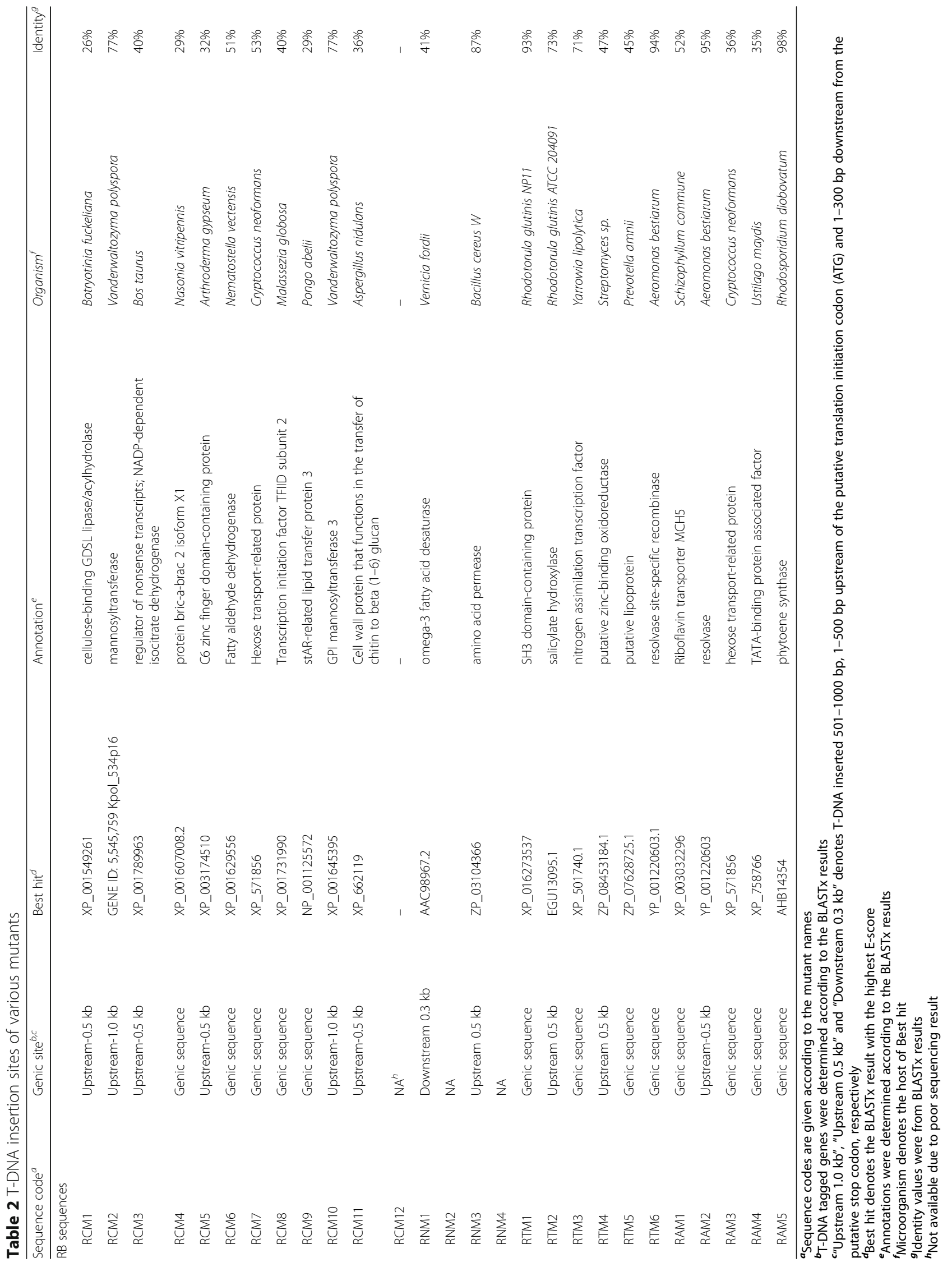




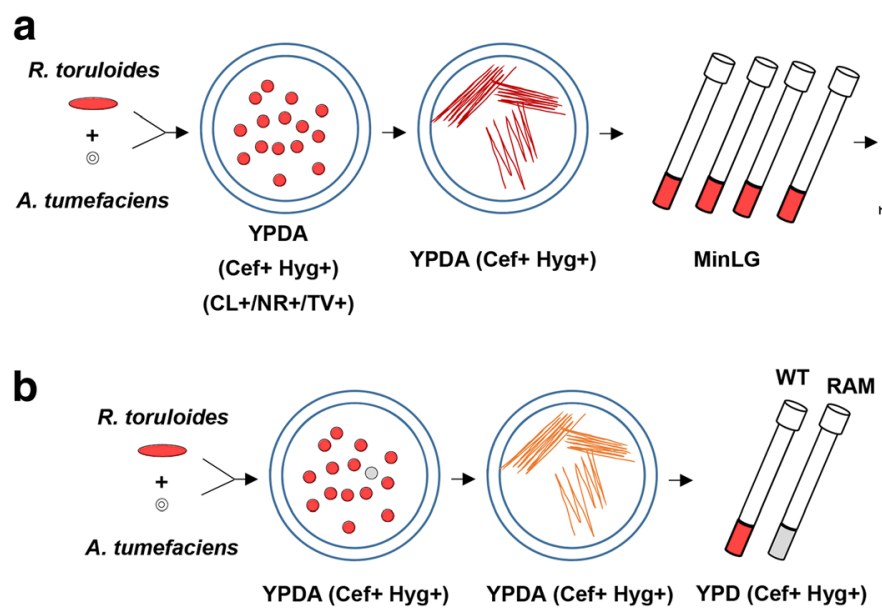

Fig. 5 Schematic diagram for gene identification based on IM. a Screening for lipid/fatty acid production mutants. b Visual screening for carotenoid production mutants. Abbreviations: $\mathrm{CL}+$, cerulenin $(50 \mu \mathrm{g} / \mathrm{mL})$; NR+, nile red $(0.5 \mu \mathrm{g} / \mathrm{mL})$; TV+, tetrazolium violet $(10 \mu \mathrm{g} / \mathrm{mL})$; Cef+, cefotaxime $(300 \mu \mathrm{g} / \mathrm{mL})$; Hyg+, hygromycin B $(150 \mu \mathrm{g} / \mathrm{mL})$

in all cases, leading to the discovery of 27 mutants in total. Importantly, many of the genes appeared to be consistent with their expected roles. For example, riboflavin transporter is involved in the uptake of riboflavin (vitamin B2) and flavin adenine dinucleotide (FAD), which are cofactors for many biocatalytic reactions [66]. Hexose transporter is involved in the uptake of monosaccharides, which is regarded as the first and rate-limiting step of glucose metabolism [67]. Most notably, disruption of the putative aldehyde dehydrogenase gene can lead to a significant increase in ALA content (see RCM6 in Fig. 6a). As a proof of concept, one of the mutants (RAM5) was validated by reverse genetics and the results were in full agreement with the prediction that the gene was involved in the biosynthesis of carotenoids. The latter has been confirmed by another laboratory recently [68]. A full characterization of the 27 mutants is expected to yield valuable information on novel strategies to improve lipid and carotenoid production in this yeast.

Single-copy integration rate, the percentage of transformants with a single copy of transgene integrated into the genome, is an important parameter for IM studies, which is particularly relevant for gene tagging work. The non-homologous end-joining (NHEJ) DNA recombination pathway is believed to be essential for ATMT [69]. Previously, ATMT of $U$. maydis using the same method yielded a single-copy integration rate of 96\% [39]. A significantly lower single-copy integration rate of $75 \%$ was observed in $R$. toruloides. This could be attributed to the weaker activity of the $U$. maydis gpd1 promoter that was used to drive the expression of hygromycin resistance gene in $R$. toruloides [16]. Indeed, single-copy integration rate was almost $100 \%$ when it was replaced with the endogenous RtGPD1 promoter (our unpublished data). The average T-DNA copy number (1.36) in Rhodotorula species remained lower than in plants, such as 1.5 in Arabidopsis [47] and 1.76-2.0 in rice [70, 71]. On the other hand, multiple-copy T-DNA integrations could result in the higher expression of target protein, which could be exploited for metabolic engineering in this yeast.

\section{Conclusions}

We have established a trackable and reliable mutagenesis method for $R$. toruloides using T-DNA as the mutagen. This method will be valuable for gene discovery as well as strain improvement in Pucciniomycotina subphylum and beyond. The 27 mutants identified in this study should yield significant novel information on the lipid and carotenoid biosynthetic pathways.

\section{Methods}

Strains, chemicals, media and culture conditions

R. toruloides strains ATCC 10657, ATCC 10788, ATCC 204091, R. glutinis strain ATCC 90781, and A. tumefaciens strain AGL1 [72] were obtained from ATCC (USA). R. graminis strain WP1 and Sporobolomyces roseus strain FGSC 10293 (IAM13481) were obtained from Fungal Genetics Stock Center, University of Missouri, USA. R. toruloides KU70 null mutant strain ku70e was described previously [26].

Hygromycin B was purchased from Roche Diagnostics (USA). Nylon $\mathrm{N}$ and $\mathrm{N}+$ membranes $(\Phi 82 \mathrm{~mm}, 0.45 \mu \mathrm{m})$ were from GE Healthcare (Uppsala, Sweden), cellulose acetate membrane $(47 \mathrm{~mm}, \Phi 0.45 \mu \mathrm{m})$ from Grace (Deerfield, IL, USA), cellulose nitrate $(87 \mathrm{~mm}, \Phi 0.45 \mu \mathrm{m})$ from Schleicher \& Schuell (Dassel, Germany) and filter paper (Grade 4, $\Phi 90 \mathrm{~mm}, 20-25 \mu \mathrm{m}$ in thickness) from Whatman (USA). Cerulenin was obtained from SigmaAldrich (USA) and prepared as a $5 \mathrm{mg} / \mathrm{mL}$ stock in DMSO. 
a

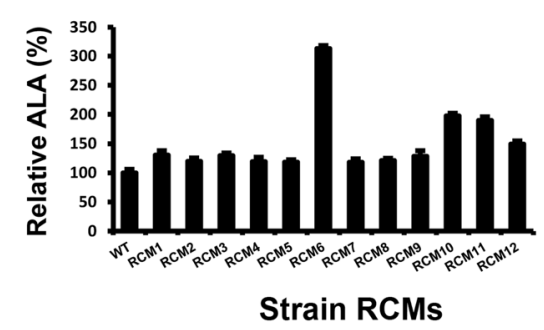

b

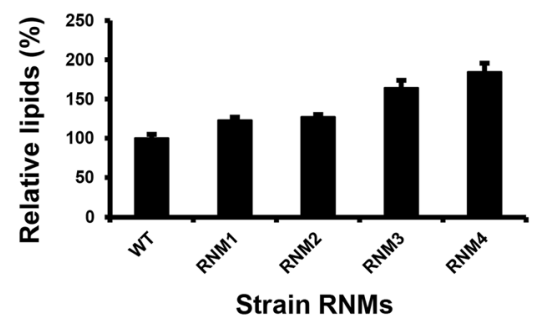

C

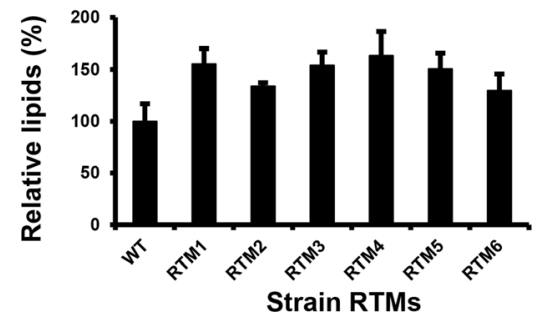

d

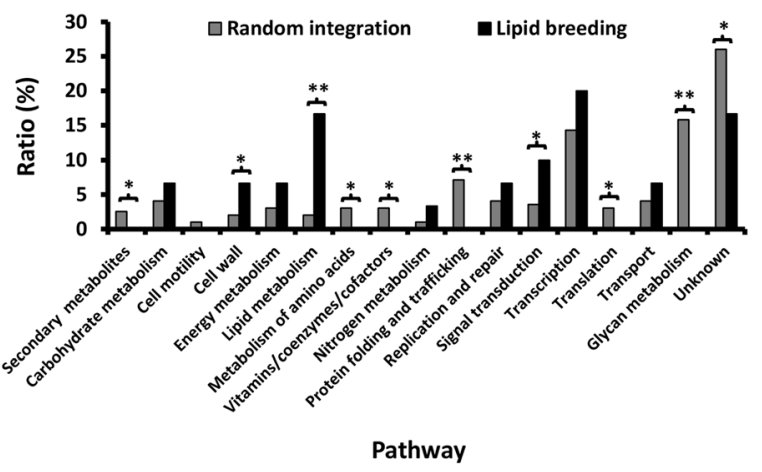

Fig. 6 Characterization of lipogenic mutants. a Relative a-Linolenic acid $\left(C 18: 3 \Delta^{9,12,15}, A L A\right)$ yields of RCM mutants. b Relative lipid contents of RNM mutants. $\mathbf{c}$ Relative lipid contents of RTM mutants. $\mathbf{d}$ Mutant classification and statistical analysis (Chi-square). 22 lipogenic mutants (RCMs, RNMs and RTMs) were plotted according to their predicted protein functions (Dark bars). The predicted percentage of protein fucntions affected were shown in grey bars. Probability: ${ }^{*} P<0.05$; $* *, P<0.01$

All other chemicals were also obtained from SigmaAldrich.

Rhodotorula strains were cultured at $28{ }^{\circ} \mathrm{C}$ in YPD broth (10 g/L yeast extract, $20 \mathrm{~g} / \mathrm{L}$ peptone, $20 \mathrm{~g} / \mathrm{L}$ glucose) or on solid potato-dextrose agar (PDA). A. tumefaciens was grown at $28{ }^{\circ} \mathrm{C}$ in either liquid or solid 2YT medium $(16 \mathrm{~g} / \mathrm{L}$ tryptone, $10 \mathrm{~g} / \mathrm{L}$ yeast extract, $5 \mathrm{~g} / \mathrm{L} \mathrm{NaCl}$ ). Carotenoid production medium B2001 was prepared as described previously [73]. It contained (per litre) $46 \mathrm{~g}$ glucose, 11.74 g yeast extract, $2 \mathrm{~g} \mathrm{~K}_{2} \mathrm{HPO}_{4}, 2 \mathrm{~g} \mathrm{KH} 2 \mathrm{PO}_{4}$, $0.1 \mathrm{~g} \mathrm{MgSO}_{4} \cdot 7 \mathrm{H}_{2} \mathrm{O}, 18 \mathrm{~g}$ threonine, $10 \mathrm{~mL}$ trace element (TE) solution, $\mathrm{pH}$ 6.0. TE solution (per litre) contained 4.0 g CaCl $2 \cdot 2 \mathrm{H}_{2} \mathrm{O}, 0.55$ g $\mathrm{FeSO}_{4} \cdot 7 \mathrm{H}_{2} \mathrm{O}, 0.52 \mathrm{~g}$ citric acid. $\mathrm{H}_{2} \mathrm{O}, 0.1 \mathrm{~g} \mathrm{ZnSO}_{4} \cdot 7 \mathrm{H}_{2} \mathrm{O}, 0.076 \mathrm{~g} \mathrm{MnSO}_{4} \cdot \mathrm{H}_{2} \mathrm{O}$ and $0.1 \mathrm{~mL}$ smoked $\mathrm{H}_{2} \mathrm{SO}_{4}$ [74]. Lipid production medium MinLG was prepared as previously described [75] with some modification. It contained (per litre) $30 \mathrm{~g}$ glucose, $1.5 \mathrm{~g}$ yeast extract, $0.5 \mathrm{~g}\left(\mathrm{NH}_{4}\right)_{2} \mathrm{SO}_{4}, 2.05 \mathrm{~g} \mathrm{~K}_{2} \mathrm{HPO}_{4}$, $1.45 \mathrm{~g} \mathrm{KH}_{2} \mathrm{PO}_{4}, 0.6 \mathrm{~g} \mathrm{MgSO}_{4} \cdot 7 \mathrm{H}_{2} \mathrm{O}, 0.3 \mathrm{~g} \mathrm{NaCl}, 10 \mathrm{mg}$ $\mathrm{CaCl}_{2}, 1 \mathrm{mg} \mathrm{FeSO}$, $0.5 \mathrm{mg} \mathrm{ZnSO}$, $0.5 \mathrm{mg} \mathrm{CuSO}, 0.5 \mathrm{mg}$ $\mathrm{H}_{3} \mathrm{BO}_{4}, 0.5 \mathrm{mg} \mathrm{MnSO}_{4}$ and $0.5 \mathrm{mg} \mathrm{NaMoO}$, pH 6.1. A seed culture in YPD broth was inoculated in medium B2001 and MinLG to initiate the production of carotenoids and lipids, respectively. Unless indicated otherwise, either lipid or carotenoid production was conducted at $28^{\circ} \mathrm{C}$ for 4 days with constant agitation $(250 \mathrm{rpm})$.

\section{DNA constructs}

Oligonucleotides used are listed in Additional file 5: Table S3. All restriction and modification enzymes were from New England Biolabs (NEB, Massachusetts, USA). Binary vectors pEX2 [16] are pPZP200 derivatives used for dominant selection against hygromycin $\mathrm{B}$.

The promoter of Ashbya gossypii translational elongation factor 1- $\alpha$ gene $\left(\mathrm{P}_{\text {tef }} 348 \mathrm{bp}\right)$ [76], Ustilago maydis gpd1 ( $\mathrm{P}_{\text {gpd }}, 595$ bp in length) [39, 77], Aspergillus nidulans gpdA ( $\left.\mathrm{P}_{\text {gpdA }}, 884 \mathrm{bp}\right)$ [78] and $R$. toruloides GPD1 ( $\mathrm{P}_{G P D 1}$, $1429 \mathrm{bp)}$ [16], were amplified from plasmid pTHPR1 [39], genomic DNA of $U$. maydis, A. nidulans and $R$. toruloides, respectively. The primer pair used for the amplication of $\mathrm{P}_{g p d}, \mathrm{P}_{g p d A}, \mathrm{P}_{t e f}$ and $\mathrm{P}_{G P D 1}$ was Pgap-Sf/Pgap-Nr, PgpdA-Sf/ PgpdA-Nr, Ptef-Sf/Ptef-Nr and Rt011S/Rt012N, respectively. The resulting DNA fragment of $\mathrm{P}_{g p d}, \mathrm{P}_{g p d A}, \mathrm{P}_{t e f}$ and $\mathrm{P}_{\text {GPD1 }}$ was double-digested with SpeI and NcoI and used in a 3-fragment ligation with the 1030-bp BspHI/ SmaI DNA fragment of the synthetic hpt-3 gene casette [16] and the 8855-bp SpeI/SacI (blunt-ended) DNA fragment of pEC3GPD-GUS (Additional file 6: Figure S3A) to create pEC3UmGPD-HPT3, pEC3GPDA-HP T3, pEC3TEFA-HPT3 and pEC3GPD1-HPT3, respectively (Additional file 6: Figure S3B).

To delete CAR1, the genome sequence ranging from -89 to +2928 from the translational start of CAR1 (AEVR02000018) was amplified using oligos Rt127-2 and Rt128-2. The resultant blunt-ended PCR product was ligated to PmeI and SacI (blunt-end) digested pEX2 to create the intemediate vector pEX2CAR1. The partial coding sequence of CAR1 in pEX2CAR1 was digested by SacII and MfeI (both blunt-ended) and replaced with the hygromycin resistance cassette $\mathrm{P}_{\text {GPD1 }}:$ hpt-3::Tnos [26] to create the gene deletion plasmid pKOCAR1. To make the complementation plasmid pRHCAR1C, the genomic 
sequence of CAR1 ranging from -662 to +2928 from the translational start was amplified using oligos Rt319Sf and Rt128-2, 5'-hydroxyl termini phosphorylated with T4 polynucleotide kinase, digested with SpeI, and inserted to the SpeI and EcoRV sites of pRH201.

\section{Nucleic acid preparations and manipulations}

Genomic DNA was isolated using MasterPure Yeast DNA Purification Kit (Epicentre Biotechnologies, Madison, WI, USA). Total RNA was prepared using the RiboPure RNA Purification Kit (ThermoFisher Scientific, Austin, TX, USA). The resulting nucleotide acids were qualified and quantified by agarose gel electrophoresis and NanoDrop ${ }^{\circ}$ ND-1000 Spectrophotometer (Nanodrop Technologies, USA), respectively.

\section{Agrobacterium tumefaciens-mediated transformation}

Fungi transformation via ATMT was performed as described previously unless indicated otherwise [16]. For membrane-free ATMT, Agrobacterium and fungi cells were mixed and spread on the surface of IM agar [16] without any supporting membranes. After co-culture at $24{ }^{\circ} \mathrm{C}$ for 2 days, cells were scrapped out using a Lshape spreader and plated on the surface of YPD agar supplemented with appropriate antibiotics as described previously [16], and incubated at $30{ }^{\circ} \mathrm{C}$ until the appearance of transformants.

\section{Southern blot analysis}

Genomic DNA was digested with PstI and separated by electrophoresis on $0.8 \%$ agarose gels. DIG-labeled probe of the partial hpt-3 gene $(+375$ through +1036$)$ was amplified using oligos HptRU and HptRSL2 (Additional file 5: Table S3). To verify CAR1 deletion mutants, genomic DNA was digested with HindIII and the digoxigeninlabeled CAR1R fragment (Fig. 7b) was used as the probe. Southern hybridization was carried out according to the manufacture's instructions (DIG-High prime DNA labeling and detection starter Kit II, Roche Diagnostics).

\section{Identification of T-DNA tagging positions}

T-DNA tagging positions in the genome were identified using hiTAIL PCR. Specific primers (HRSP1, HRSP2 and HRSP3) and arbitrary primers (LAD1-1 and LAD1-4) were used for LB flanking sequences. Specific primers (HRRSP1, HRRSP2 and HRRSP3) and arbitrary primers (LAD1-1 and LAD1-4) for RB flanking sequences. PCR were carried out with i-Taq DNA polymerase (i-DNA Biotech, Singapore) in a PTC-200 $0^{\text {max }}$ Programmable Thermal Controller (Bio-Rad, USA). PCR products were purified using gel extraction kit (Qiagen, CA, USA) and sequenced using the Big Dye v3.1 terminator kit (Applied Biosystems, USA) with oligo HRSP3 (for LB) or HRRSP3 (for RB). In some cases, PCR products were cloned into PGEM-T easy vector (Promega, USA) by TA cloning technique and sequenced using oligos M13FP and M13RP.

\section{Quantitative reverse transcription PCR (qRT-PCR)}

qRT-PCR was performed in triplicates as described [21]. Relative gene expression levels were calculated against the reference gene ACT1 (actin encoding gene, GenBank acc. no. KR138696) [17] using the $2^{-\Delta \Delta C t}$ method (RQ Manager software v1.2.1, Applied Biosystems). Oligonucleotide pair used for CAR1 and ACT1 was qCAR1f/ qCAR1r and qACT1f/qACT1r, respectively.

\section{Screening for lipid and carotenoid production mutants}

The genome of $R$. toruloides was mutagenized by random insertion of T-DNA of plasmid pRH201. Candidate lipid production mutants were selected by supplementation of various chemicals, such as $50 \mu \mathrm{g} / \mathrm{mL}$ cerulenin, $0.5 \mu \mathrm{g} / \mathrm{mL}$ nile red or $10 \mu \mathrm{g} / \mathrm{mL}$ tetrazolium violet. After incubation at $28{ }^{\circ} \mathrm{C}$ for 5 days, transformants that survived cerulenin treatment (Additional file 4: Figure S2A), showing higher fluorescent intensity on nile red-containing media or darker purple-color pigmentation (Additional file 4: Figure S2B) on tetrazolium violet-containing media (Additional file 4: Figure S2C), were transferred to YPD broth $(300 \mu \mathrm{g} / \mathrm{mL}$ cefotaxime and $150 \mu \mathrm{g} / \mathrm{mL}$ hygromycin) for propagation and cryopreservation. Candidate carotenoid production mutants were selected by visual screening of transformants.

\section{Extraction of lipids and carotenoids}

Total lipid was extracted essentially as described previously [79]. Dry cell biomass (10 mg) was mixed with $500 \mu \mathrm{l}$ of $4 \mathrm{M} \mathrm{HCl}$ and incubated in a boiling water bath for $15 \mathrm{~min}$. Subsequently, samples were placed in a $-20{ }^{\circ} \mathrm{C}$ freezer for at least $1 \mathrm{~h}$ and cell lysates were mixed with $1.0 \mathrm{mg}$ pentadecanoic acid (C15:0, the internal standard for the subsequent $\mathrm{GC}$ analysis) and $1.0 \mathrm{~mL}$ chloroform: methanol $(2: 1, v / v)$. After centrifugation, the lower solvent phase was transferred to a new tube. The total lipid mass was determined by weighing after drying in a vacuum concentrator (Eppendorf, USA).

Extraction of carotenoids was performed as described previously [80]. Birefly, cells from $50 \mathrm{~mL}$ cultures were pelleted by centrifugation and washed twice with water. Equal amount of acid-washed glass beads $(0.4-0.6 \mathrm{~mm}$ in dimeter, Sigma-Aldirch) and $5 \mathrm{~mL}$ DMSO were added and mixed vigorously for $10 \mathrm{~min}$ by vortexing. After incubated at $65{ }^{\circ} \mathrm{C}$ for $1 \mathrm{~h}$, freezed at $-20{ }^{\circ} \mathrm{C}$ for $30 \mathrm{~min}$ and centrifuged, the supernatants were removed to a new tube (DMSO-dissolved carotenoids). The pellets were mixed with $30 \mathrm{~mL}$ of light petrolium ether-ethyl acetate $(2: 1, \mathrm{v} / \mathrm{v})$ for $10 \mathrm{~min}$ by vigorous vortexing. After centrifugation, the supernatants (solvent-dissolved carotenoids) were combined with previous DMSO-dissolved carotenoids and then $2 \mathrm{~mL}$ of saturated $\mathrm{NaCl}$ solution was added. 
a

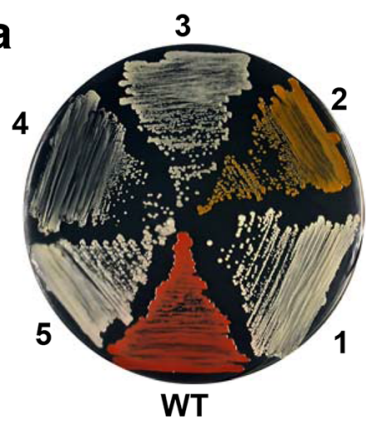

C

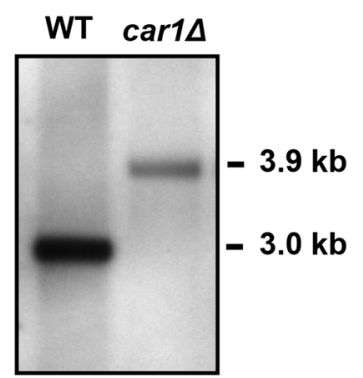

b
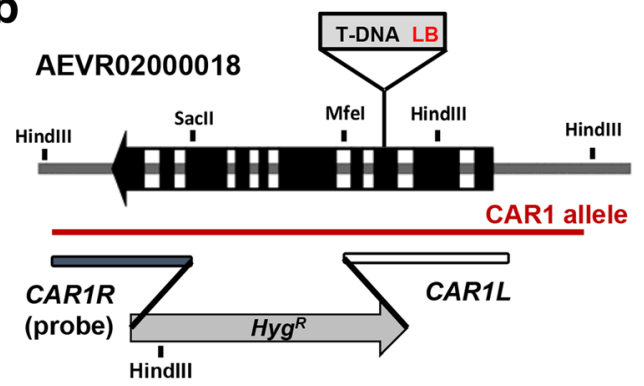

d

WT car1s car1C

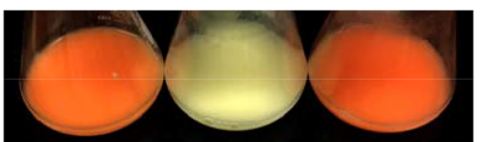

Liquid broth

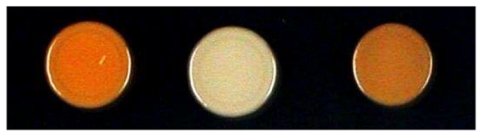

Agar

e

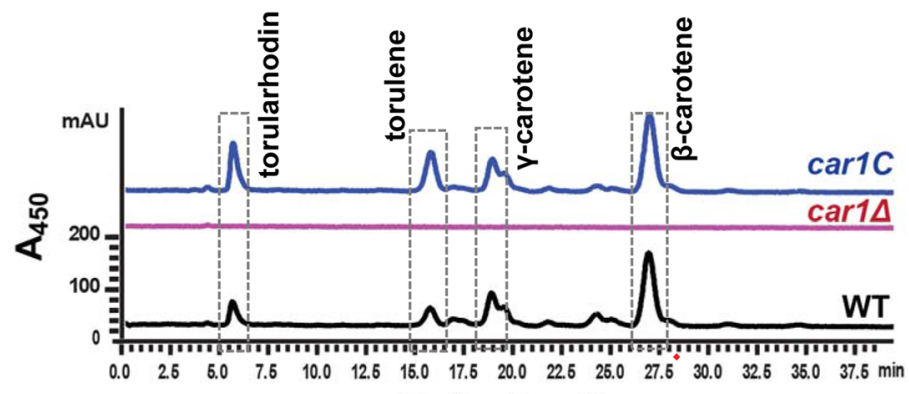

Retention time

f

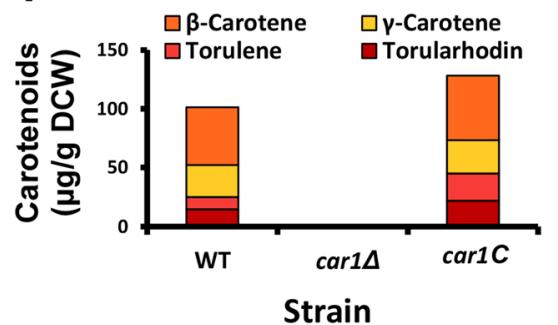

9

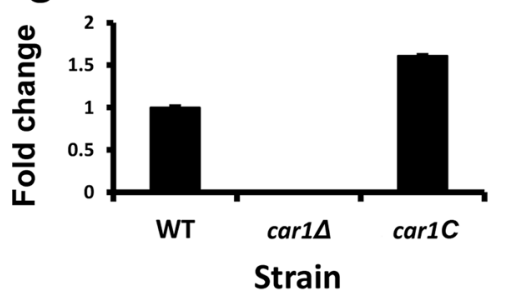

Fig. 7 Identification of carotenogenic mutants and functional validation of RAM5. a Colony color phenotypes of RAMs. All strains were streaked on PDA plate and incubated at $28^{\circ} \mathrm{C}$ for 2 days. $\mathbf{b}$ Schematic diagram of CAR1 structure and its deletion and complementation strategies. CAR1 genomic sequence (Dark red line) ranging from -662 to +2928 was used to complement the car1 mutant. c Southern blot hybridization of candidate CAR1 null mutant (car1 $\Delta$ ). $\mathbf{d}$ Pigment colors of WT, null mutant (car1 $\Delta$ ) and complementation strain (car1C) in either liquid broth or agar medium. e HPLC chromatogram of carotenoids from WT, car1 $\Delta$ and car1C. All strains were cultured in medium B2001 for 5 days. $\mathbf{f}$ Quantitative analysis of 4 different carotenoid species (microgram of carotenoid per dry cell weight, $\mu \mathrm{g} / \mathrm{g}$ DCW) in WT, car1 $\Delta$ and car1C strains. $\mathbf{g}$ Changes of CAR1 mRNA levels in WT, car1 1 , and car1C. All cells were cultured in carotenoid production media B2001 for 1 day before RNA extraction. Actin encoding gene (ACT1) was used as the reference

The upper solvent phase was separated and blow-dried with nitrogen gas and carotenoids was re-dissolved in hexane.

\section{Quantification methods}

Cell biomass (dry cell weight) was determined by lyophilizing the cell pellet until constant weight was reached. 
Residual glucose was quantified by HPLC in a Prominence ultra fast liquid chromatography (UFLC) system (Shimadzu, Kyoto, Japan). Culture was filtered through a $0.2 \mu \mathrm{m}$ nylon membrane and run through a $300 \times 7.0 \mathrm{~mm}$ Aminex $87 \mathrm{H}$ column (Bio-Rad) at a constant flow rate of $0.7 \mathrm{~mL} / \mathrm{min}$ using $5 \mathrm{mM}$ sulfuric acid as the mobile phase. The column was maintained at $50{ }^{\circ} \mathrm{C}$ and glucose was detected with a Refractive Index Detector (RID, Shimadzu). Concentration of glucose in the cell culture was determined using calibration curves built with the standard glucose aqueous solution.

Quick estimation of lipid content was performed as described previously [59]. Briefly, $10 \mu \mathrm{l}$ cell culture and $2 \mu \mathrm{l}$ nile red stock (50 $\mathrm{mM}$ in acetone) were mixed with $200 \mu \mathrm{l}$ PBS buffer (pH 7.4) in a well of a FluoroNunc plate (Thermo Fisher Scientific, Langenselbold, Germany). Each sample was accompanied with a nile red-free well as the background control. Another fraction of the cell culture $(10 \mu \mathrm{l})$ was mixed with $90 \mu \mathrm{l}$ PBS buffer $(\mathrm{pH}$ 7.4) in a 96-well flat-bottom transparent plate (Nunc, Roskilde, Denmark) to measure cell optical density. The data was acquired and analyzed using the Infinite M200 plate reader and the iControl ${ }^{\mathrm{Ta}}$ version 3.0 software (Tecan, Salzburg, Austria). Cell optical density was read at $600 \mathrm{~nm}$ after subtracting background while fluorescence intensity was measured with an excitation and emission wavelength of $488 \mathrm{~nm}$ and $508 \mathrm{~nm}$, respectively. The relative lipid content was calculated by normalization against its absorptance at $600 \mathrm{~nm}$ after deducting the background control. Statistical triplicates were used for all tests.

Fatty acid profiles were determined by gas chroma tography-mass spectrometry (GCMS). Preparation of fatty acid methyl esters (FAMEs) and subsequent GCMS analysis were performed as described previously [81]. Briefly, lipids were dissolved in $300 \mu \mathrm{l}$ petroleum etherbenzene $(1: 1, v / v)$, mixed with equal volume of methanolic hydrochloride acid ( $3 \mathrm{M}$, Sigma) and kept at $80{ }^{\circ} \mathrm{C}$ for $1 \mathrm{~h}$. FAMEs were extracted with $1 \mathrm{~mL}$ of hexane, and $1 \mu \mathrm{L}$ was injected to a HP-88 fused silica capillary column (30$\mathrm{m}$ length, $0.25-\mu \mathrm{m}$ diameter, and $0.25-\mathrm{mm}$ film thickness, Agilent J\&W Scientific, Folsom, CA, USA) fitted in a GCMS (QP2010 Ultra, Shimadzu). The running conditions were typically $42.3 \mathrm{~mL} / \mathrm{min}$ nitrogen flow, $150^{\circ} \mathrm{C}$ for starting temperature $(3 \mathrm{~min})$, a 15 - $\mathrm{min}$ ramp to $240{ }^{\circ} \mathrm{C}$, and holding at $240{ }^{\circ} \mathrm{C}$ for $7 \mathrm{~min}$. The FAME peaks were identified by searching against Shimadzu NIST08 compound library and quantified as percentages of total fatty acids (\%TFA).

The total carotenoid concentration was estimated by spectrophotometry method [82]. Briefly, the absorbance of carotenoids in petroleum ester was measured at $485 \mathrm{~nm}$ $\left(A_{485}\right)$ and the carotenoid concentration was calculated using the following formula: Carotenoids $(\mathrm{mg} / \mathrm{L})=A_{485} \times$
$1000 / 2680$, where the coefficient of absorbance used was that equivalent to $\beta$-carotene: $E_{1}^{1 \%}{ }_{\mathrm{cm}}=2680$ for petroleum ether. The carotenoid species were quantified by HPLC (Shimadzu Prominence UFLC system coupled with photodiode array detector) as previously described [83]. Briefly, carotenoids were filtered through a $0.2 \mu$ m nylon membrane and separated through the Kinetex C18 reverse phase column $(100 \times 3 \mathrm{~mm}, \phi 2.6 \mu \mathrm{m}$, Phenomenex Inc., CA, USA) at a constant temperature of $35^{\circ} \mathrm{C}$. The mobile phase (acetonitrile:methanol containing 0.1 M ammonium acetate: dichloromethane $=71: 22: 7, \mathrm{v} / \mathrm{v} / \mathrm{v}$ ) was run at a constant flow rate of $0.3 \mathrm{~mL} / \mathrm{min}$. Various carotenoid compositions were quantified using $\beta$-carotene (C-4582, Sigma-Aldrich) as the external standard.

\section{Additional files}

Additional file 1: Figure S1. Optimization of transformation conditions. Unless indicated otherwise, the same volume $(100 \mu \mathrm{L})$ of $R$. toruloides strain ATCC 10657 and A. tumefaciens strain AGL1 harboring plasmid pRH201 were co-cultured on IM agar (pH 5.5 and Nylon N+ membrane) for two days, and subsequently selected on YPD agar medium $(150 \mu \mathrm{g} / \mathrm{mL}$ hygromycin and $300 \mu \mathrm{g} / \mathrm{mL}$ cefotaxime) for 4 days. (A) The presence $(+)$ and absence (-) of acetosyringone $(100 \mu \mathrm{g} / \mathrm{mL})$. (B) Co-culture time. (C) Volumetric ratio of fungi to Agrobacteria. $100 \mu \mathrm{L}$ of fungal cells were co-cultured with 10 to $100 \mu \mathrm{L}$ AGL1 (pRH201) on induction medium before selection. (D) Effect of various promoters for the expression of the synthetic hpt-3 gene. Um gpd1, Rt GPD1 and An gpdA represents the glyceraldehyde-3-phospohate dehydrogenase promoter of U. maydis (0.6 kb), R. toruloides (1.4 kb), and Aspergillus nidulans ( $0.8 \mathrm{~kb})$, respectively. Ag tef represents the promoter of Ashbya gossypii translation elongation factor (245 bp). Transformation efficiency (TFE) was represented as the relative percentage value against the highest colony forming unit (CFU) observed in the trial. Biological triplicates were used and error bars represent the standard derivations. (PDF $85 \mathrm{~kb}$ )

Additional file 2: Table S1. Locations of 61 T-DNA left border flanking sequences. (PDF $91 \mathrm{~kb}$ )

Additional file 3: Table S2. Summary of 192 T-DNA flanking sequences in the R. glutinis ATCC 204091 genome. (PDF 159 kb)

Additional file 4: Figure S2. Chemical-assisted and visual screening systems. (A) Cerulenin-assisted screening for high PUFA producing mutants. - and + represents the absence and presence of $50 \mu \mathrm{g} / \mathrm{mL}$ cerulenin, respectively. (B) Nile red-assisted screening for high lipid producing mutants. $\mathrm{L}$ and $\mathrm{H}$ represents the low and high fluorescence intensity on $0.5 \mu \mathrm{g} / \mathrm{mL}$ nile red-containing YPD agar, respectively. (C) Tetrazeolium violet-assisted screening for high lipid producing mutants. L and $\mathrm{H}$ represents the low and high violet intensity on $10 \mu \mathrm{g} / \mathrm{mL}$ tetrazolium violet-containing YPD agar, respectively. (D) Visual screening for carotenoid producing mutants (indicated by arrow heads). (PDF 854 kb)

Additional file 5: Table S3. Sequences of oligonucleotides. (PDF $75 \mathrm{~kb}$ )

Additional file 6: Figure S3. T-DNA organizations in contructs used in this study. All binary vectors have the same pPZP200 backbone [84]. (A) pEC3Pxxx-HPT3. (B) pEC3GPD-GUS. LB: left border of T-DNA; RB: right border of T-DNA; PXXX represents three glyceraldehydes-3-phosphate dehydrogenase promoters from $A$. nidulans $\left(P_{g p d A}\right), U$. maydis $\left(P_{g p d}\right)$ and $R$. toruloides $\left(\mathrm{P}_{G P D_{1}}\right)$ and the tranlation elongation factor promoter from A. gossypii $\left(\mathrm{P}_{\text {tef }}\right)$. hpt-3: codon-optimized hygromycin resistance gene based on the codon usage bias in R. toruloides; GUS: E. coli $\beta$-glucuronidase gene; $T_{35}$ : terminator of cauliflower mosaic virus 355 gene; Tnos: terminator of $A$. tumefaciens nopaline synthase gene; $T_{\text {tef. }}$ terminator of $A$. gossypii translation elongation factor gene; $T_{c y c i}$ : Terminator of $S$. cerevisiae iso-1-cytochrome C gene. The labeled restriction enzymes are unique cutting sites in the plasmid. (PDF $56 \mathrm{~kb}$ ) 


\section{Abbreviations}

ATCC: American Type Culture Collection, USA; BLAST: Basic Local Alignment Search Tool (National Library of Medicine, National Institutes of Health, USA); CAR1: Phytoene desaturase gene; DCW: Dry cell weight; GPD1: Glyceraldehyde 3-phosphate dehydrogenase gene; hpt-3: A synthetic E. coli hygromycin B phosphotransferase gene optimized according to the codon bias of $R$. toruloides; IM: Insertional mutagenesis; PUFA: Polyunsaturated fatty acid; RACE: Rapid amplification of CDNA ends; TFE: Transformation efficiency; UTR: Untranslated region; WT: Wild-type strain

\section{Acknowledgements}

Not applicable

\section{Funding}

This work was financially supported by Singapore National Research Fundation under the Competitive Research Program (CRP-8-2011-02), Singapore Economic Development Board and Temasek Trust. All above funding bodies have no roles in the design of the study, collection of data, analysis and interpretation of data and writing of the manuscript.

\section{Availability of data and materials}

The datasets supporting the conclusions of this article are included within the article and its additional files. The datasets used and/or analyzed during the current study are available from the corresponding author on reasonable request.

\section{Authors' contributions}

$Y L$ and $L J$ conceived and designed the experiments. $Y L$ and CMJK performed ATMT, sequence analysis, gene deletion, real-time PCR, Southern blot hybridization and physiological studies. SAY contributed to plasmid construction, ATMT, sequence analysis, lipid quantification and fatty acid profiling. MD and MMH contributed to identification of mutants. YL, CMJK, SAY, MD and MMH interpreted the data. YL and CMJK prepared the figures and Tables. $Y L$ and $L J$ drafted and revised the manuscript. All authors read and approved the final manuscript.

\section{Ethics approval and consent to participate}

Not applicable

\section{Consent for publication}

Not applicable

\section{Competing interests}

The authors declare that they have no competing interests. Temasek Life Sciences Laboratory has an interest in developing Rhodotorula toruloides as an industrial biotechnology platform

\section{Publisher's Note}

Springer Nature remains neutral with regard to jurisdictional claims in published maps and institutional affiliations.

\section{Author details}

${ }^{1}$ Biomaterials and Biocatalysts Group, Temasek Life Sciences Laboratory, 1 Research Link, National University of Singapore, Singapore 117604 , Singapore. ${ }^{2}$ School of Biological Sciences, Nanyang Technological University, 60 Nanyang Drive, Singapore 637551, Singapore.

Received: 4 July 2017 Accepted: 30 January 2018 Published online: 21 February 2018

\section{References}

1. Ratledge C. Regulation of lipid accumulation in oleaginous microorganisms. Biochem Soc Trans. 2002;30(Pt 6):1047-50.

2. Turcotte G, Kosaric N. Lipid biosynthesis in oleaginous yeasts. In: Bioprocesses and Engineering, vol. vol. 40. Heidelberg: Springer Berlin; 1989. p. 73-92.

3. Ratledge C, Wynn JP. The biochemistry and molecular biology of lipid accumulation in oleaginous microorganisms. Adv Appl Microbiol. 2002:51:1-51.

4. Rossi M, Amaretti A, Raimondi S, Leonardi A. Getting lipids for biodiesel production from oleaginous fungi. In: Biodiesel: Feedstocks and Processing Technologies Edited by Stoytcheva M, Montero G. Rijeka: InTech. 2011. p. 71-92.

5. Papanikolaou S, Aggelis G. Lipids of oleaginous yeasts. Part II: technology and potential applications. Eur J Lipid Sci Technol. 2011;113(8):1052-73.
6. Gong Z, Shen H, Wang Q, Yang X, Xie H, Zhao ZK. Efficient conversion of biomass into lipids by using the simultaneous saccharification and enhanced lipid production process. Biotechnol Biofuels. 2013;6(1):1-12.

7. Meng X, Yang J, Xu X, Zhang L, Nie Q, Xian M. Biodiesel production from oleaginous microorganisms. Renew Energy. 2009;34(1):1-5.

8. Vachali P, Bhosale P, Bernstein PS. Microbial carotenoids. In: Barredo JL, editor. Microbial carotenoids from fungi: methods and protocols, vol. vol. 898. New York: springer science+business Media; 2012. p. 41-59.

9. Wang QM, Yurkov AM, Goker M, Lumbsch HT, Leavitt SD, Groenewald M, Theelen B, Liu XZ, Boekhout T, Bai FY. Phylogenetic classification of yeasts and related taxa within Pucciniomycotina. Stud Mycol. 2015;81:149-89.

10. Li Y, Zhao ZK, Bai F. High-density cultivation of oleaginous yeast Rhodosporidium toruloides Y4 in fed-batch culture. Enzym Microb Technol. 2007:41(3):312-7.

11. Zhao X, Hu C, Wu S, Shen H, Zhao ZK. Lipid production by Rhodosporidium toruloides Y4 using different substrate feeding strategies. J Ind Microbiol Biotechnol. 2011:38(5):627-32.

12. Pan JG, Kwak MY, Rhee JS. High density cell culture of Rhodotorula glutinis using oxygen-enriched air. Biotechnol Lett. 1986;8(10):715-8.

13. Yu X, Zheng Y, Dorgan KM, Chen S. Oil production by oleaginous yeasts using the hydrolysate from pretreatment of wheat straw with dilute sulfuric acid. Bioresour Technol. 2011;102(10):6134-40.

14. Liu H, Zhao X, Wang F, Jiang X, Zhang S, Ye M, Zhao ZK, Zou H. The proteome analysis of oleaginous yeast Lipomyces starkeyi. FEMS Yeast Res. 2011;11(1):42-51.

15. Cheirsilp B, Louhasakul Y. Industrial wastes as a promising renewable source for production of microbial lipid and direct transesterification of the lipid into biodiesel. Bioresour Technol. 2013:142:329-37.

16. Liu Y, Koh CM, Sun L, Hlaing MM, Du M, Peng N, Ji L. Characterization of glyceraldehyde-3-phosphate dehydrogenase gene RtGPD1 and development of genetic transformation method by dominant selection in oleaginous yeast Rhodosporidium toruloides. Appl Microbiol Biotechnol. 2013;97(2):719-29.

17. Liu Y, Koh CMJ, Ngoh ST, Ji L. Engineering an efficient and tight D-amino acid-inducible gene expression system in Rhodosporidium/Rhodotorula species. Microb Cell Factories. 2015;14(1):170-85.

18. Lin X, Wang Y, Zhang S, Zhu Z, Zhou YJ, Yang F, Sun W, Wang X, Zhao ZK Functional integration of multiple genes into the genome of the oleaginous yeast Rhodosporidium toruloides. FEMS Yeast Res. 2014;14(4):547-55.

19. Wang Y, Lin X, Zhang S, Sun W, Ma S, Zhao ZK. Cloning and evaluation of different constitutive promoters in the oleaginous yeast Rhodosporidium toruloides. Yeast. 2016;33(3):99-106.

20. Johns AM, Love J, Aves SJ. Four inducible promoters for controlled gene expression in the oleaginous yeast Rhodotorula toruloides. Front Microbiol. 2016:7:1666.

21. Liu Y, Yap SA, Koh CM, Ji L. Developing a set of strong intronic promoters for robust metabolic engineering in oleaginous Rhodotorula (Rhodosporidium) yeast species. Microb Cell Factories. 2016;15(1):200

22. Zhang S, Skerker JM, Rutter CD, Maurer MJ, Arkin AP, Rao CV. Engineering Rhodosporidium toruloides for increased lipid production. Biotechnol Bioeng 2016:113(5):1056-66

23. Zhang S, Ito M, Skerker JM, Arkin AP, Rao CV. Metabolic engineering of the oleaginous yeast Rhodosporidium toruloides IFO0880 for lipid overproduction during high-density fermentation. Appl Microbiol Biotechnol. 2016;100:9393-405.

24. Wang $Y$, Zhang S, Potter M, Sun W, Li L, Yang $X$, Jiao X, Zhao ZK. Overexpression of $\Delta 12$-fatty acid desaturase in the oleaginous yeast Rhodosporidium toruloides for production of linoleic acid-rich lipids. Appl Biochem Biotechnol. 2016;180(8):1497-507.

25. Lee JJ, Chen L, Cao B, Chen WN. Engineering Rhodosporidium toruloides with a membrane transporter facilitates production and separation of carotenoids and lipids in a bi-phasic culture. Appl Microbiol Biotechnol. 2016:100(2):869-77.

26. Koh CM, Liu Y, Du M, Ji L. Molecular characterization of KU70 and KU80 homologues and exploitation of a KU70-deficient mutant for improving gene deletion frequency in Rhodosporidium toruloides. BMC Microbiol. 2014;14(1):50

27. Conrad TM, Lewis NE, Palsson BO. Microbial laboratory evolution in the era of genome-scale science. Mol Syst Biol. 2011;7:509.

28. Brenner S. The genetics of Caenorhabditis elegans. Genetics. 1974;77(1):71-94.

29. Schneeberger K. Using next-generation sequencing to isolate mutant genes from forward genetic screens. Nat Rev Genet. 2014;15(10):662-76. 
30. Parinov S, Sundaresan V. Functional genomics in Arabidopsis: large-scale insertional mutagenesis complements the genome sequencing project. Curr Opin Biotechnol. 2000;11(2):157-61.

31. Amsterdam A, Burgess S, Golling G, Chen W, Sun Z, Townsend K, Farrington S, Haldi M, Hopkins N. A large-scale insertional mutagenesis screen in zebrafish. Genes Dev. 1999;13(20):2713-24.

32. Gragerov A, Horie K, Pavlova M, Madisen L, Zeng H, Gragerova G, Rhode A, Dolka I, Roth P, Ebbert A, et al. Large-scale, saturating insertional mutagenesis of the mouse genome. Proc Natl Acad Sci U S A. 2007;104(36):14406-11.

33. Dent RM, Sharifi MN, Malnoe A, Haglund C, Calderon RH, Wakao S, Niyogi KK. Large-scale insertional mutagenesis of Chlamydomonas supports phylogenomic functional prediction of photosynthetic genes and analysis of classical acetate-requiring mutants. Plant J. 2015;82(2):337-51.

34. Hensel M, Holden DW. Molecular genetic approaches for the study of virulence in both pathogenic bacteria and fungi. Microbiology. 1996;142(Pt 5): 1049-58.

35. Brown JS, Holden DW. Insertional mutagenesis of pathogenic fungi. Curr Opin Microbiol. 1998;1(4):390-4.

36. Liu Y, Koh CM, Sun L, Ji L. Tartronate semialdehyde reductase defines a novel rate-limiting step in assimilation and bioconversion of glycerol in Ustilago maydis. PLoS One. 2011;6(1):e16438.

37. Liu YG, Chen Y. High-efficiency thermal asymmetric interlaced PCR for amplification of unknown flanking sequences. Biotechniques. 2007:43(5): 649-50. 652, 654 passim

38. Liu YG, Whittier RF. Thermal asymmetric interlaced PCR: automatable amplification and sequencing of insert end fragments from P1 and YAC clones for chromosome walking. Genomics. 1995;25(3):674-81.

39. Ji L, Jiang ZD, Liu Y, Koh CM, Zhang LH. A simplified and efficient method for transformation and gene tagging of Ustilago maydis using frozen cells. Fungal Genet Biol. 2010;47(4):279-87.

40. Koncz C, Martini N, Mayerhofer R, Koncz-Kalman Z, Korber H, Redei GP, Schell J. High-frequency T-DNA-mediated gene tagging in plants. Proc Natl Acad Sci U S A. 1989;86(21):8467-71.

41. Ross-Macdonald P, Coelho PS, Roemer T, Agarwal S, Kumar A, Jansen R, Cheung KH, Sheehan A, Symoniatis D, Umansky L, et al. Large-scale analysis of the yeast genome by transposon tagging and gene disruption. Nature. 1999:402(6760):413-8.

42. Frandsen RJ. A guide to binary vectors and strategies for targeted genome modification in fungi using Agrobacterium tumefaciens-mediated transformation. J Microbiol Methods. 2011;87(3):247-62

43. Ziemienowicz A, Tzfira T, Hohn B. In: Tzfira T, Citovsky V, editors. Mechanisms of T-DNA integration Agrobacterium: From Biology to Biotechnology. New York: Springer; 2008. p. 395-440.

44. Michielse CB, Hooykaas PJ, van den Hondel CA, Ram AF. Agrobacteriummediated transformation as a tool for functional genomics in fungi. Curr Genet. 2005:48(1):1-17.

45. Donofrio NM, Oh Y, Lundy R, Pan H, Brown DE, Jeong JS, Coughlan S, Mitchell TK, Dean RA. Global gene expression during nitrogen starvation in the rice blast fungus, Magnaporthe grisea. Fungal Genet Biol. 2006:43(9):605-17.

46. Johnston GC, Singer RA, McFarlane S. Growth and cell division during nitrogen starvation of the yeast Saccharomyces cerevisiae. J Bacteriol. 1977;132(2):723-30.

47. Alonso JM, Stepanova AN, Leisse TJ, Kim CJ, Chen H, Shinn P, Stevenson DK, Zimmerman J, Barajas P, Cheuk R, et al. Genome-wide insertional mutagenesis of Arabidopsis thaliana. Science. 2003;301(5633):653-7.

48. Bundock P, Den Dulk-Ras A, Beijersbergen A, PJJ H. Trans-kingdom T-DNA transfer from Agrobacterium tumefaciens to Saccharomyces cerevisiae. EMBO J. 1995;14(13):3206-14

49. Choi J, Park J, Jeon J, Chi MH, Goh J, Yoo SY, Park J, Jung K, Kim H, Park SY, et al. Genome-wide analysis of T-DNA integration into the chromosomes of Magnaporthe oryzae. Mol Microbiol. 2007;66(2):371-82.

50. Mayerhofer R, Koncz-Kalman Z, Nawrath C, Bakkeren G, Crameri A, Angelis K, Redei GP, Schell J, Hohn B, Koncz C. T-DNA integration: a mode of illegitimate recombination in plants. EMBO J. 1991;10(3):697-704.

51. Kunik T, Tzfira T, Kapulnik Y, Gafni Y, Dingwall C, Citovsky V. Genetic transformation of HeLa cells by Agrobacterium. Proc Natl Acad Sci U S A. 2001;98(4):1871-6.

52. Omura S. The antibiotic cerulenin, a novel tool for biochemistry as an inhibitor of fatty acid synthesis. Bacteriol Rev. 1976;40(3):681-97.
53. Vance D, Goldberg I, Mitsuhashi O, Bloch K. Inhibition of fatty acid synthetases by the antibiotic cerulenin. Biochem Biophys Res Commun. 1972;48(3):649-56

54. Nguyen LN, Nosanchuk JD. The inhibitory effect of cerulenin to yeasts is fungicidal. Commun Integr Biol. 2011;4(6):631-2.

55. Morita N, Nishida T, Tanaka M, Yano Y, Okuyama H. Enhancement of polyunsaturated fatty acid production by cerulenin treatment in polyunsaturated fatty acid-producing bacteria. Biotechnol Lett. 2005;27(6):389-93.

56. Wang J, Li R, Lu D, Ma S, Yan Y, Li W. A quick isolation method for mutants with high lipid yield in oleaginous yeast. World J Microbiol Biotechnol. 2009; 25(5):921-5.

57. Zhong $Y$, Wang $X, Y u$ H, Liang $S$, Wang T. Application of T-DNA insertional mutagenesis for improving cellulase production in the filamentous fungus Trichoderma reesei. Bioresour Technol. 2012;110:572-7.

58. Greenspan P, Mayer EP, Fowler SD. Nile red: a selective fluorescent stain for intracellular lipid droplets. J Cell Biol. 1985;100(3):965-73.

59. Kimura K, Yamaoka M, Kamisaka Y. Rapid estimation of lipids in oleaginous fungi and yeasts using Nile red fluorescence. J Microbiol Methods. 2004:56(3):331-8.

60. Spiekermann P, Rehm BH, Kalscheuer R, Baumeister D, Steinbuchel A. A sensitive, viable-colony staining method using Nile red for direct screening of bacteria that accumulate polyhydroxyalkanoic acids and other lipid storage compounds. Arch Microbiol. 1999;171(2):73-80.

61. Zhao YF, Kong QZ. Tetrazolium violet inhibits cell growth and induces cell death in C127 mouse breast tumor cells. Chem Biol Interact. 2008;174(1):19-26

62. Peterson WJ, Evans WR, Lecce E, Bell TA, Etchells JL. Quantitative determination of the carotenoids in yeasts of the genus Rhodotorula. J Bacteriol. 1958;75(5): 586-91.

63. Perrier V, Dubreucq E, Galzy P. Fatty acid and carotenoid composition of Rhodotorula strains. Arch Microbiol. 1995;164(3):173-9.

64. Buzzini $P$, Innocenti M, Turchetti B, Libkind D, van Broock M, Mulinacci N. Carotenoid profiles of yeasts belonging to the genera Rhodotorula, Rhodosporidium, Sporobolomyces, and Sporidiobolus. Can J Microbiol. 2007:53(8):1024-31.

65. Sun L, Yan M, Ding Z, Liu Y, Du M, Xi P, Liao J, Ji L, Jiang Z. Improved dominant selection markers and co-culturing conditions for efficient Agrobacterium tumefaciens-mediated transformation of Ustilago scitaminea. Biotechnol Lett. 2014;36(6):1309-14.

66. Reihl P, Stolz J. The monocarboxylate transporter homolog Mch5p catalyzes riboflavin (vitamin B2) uptake in Saccharomyces cerevisiae. J Biol Chem. 2005;280(48):39809-17.

67. Ozcan S, Johnston M. Function and regulation of yeast hexose transporters. Microbiol Mol Biol Rev. 1999;63(3):554-69.

68. Sun $W$, Yang $X$, Wang $X$, Lin $X$, Wang $Y$, Zhang $S$, Luan $Y$, Zhao ZK. Homologous gene targeting of a carotenoids biosynthetic gene in Rhodosporidium toruloides by Agrobacterium-mediated transformation. Biotechnol Lett. 2017;

69. van Attikum H, Bundock P, Hooykaas PJJ. Non-homologous end-joining proteins are required for Agrobacterium T-DNA integration. EMBO J. 2001;20(22):6550-8.

70. Sallaud C, Meynard D, van Boxtel J, Gay C, Bes M, Brizard JP, Larmande P, Ortega D, Raynal M, Portefaix M, et al. Highly efficient production and characterization of T-DNA plants for rice ( Oryza sativa L.) functional genomics. Theor Appl Genet. 2003;106(8):1396-408.

71. Sha Y, Li S, Pei Z, Luo L, Tian Y, He C. Generation and flanking sequence analysis of a rice T-DNA tagged population. Theor Appl Genet. 2004;108(2):306-14.

72. Lazo GR, Stein PA, Ludwig RA. A DNA transformation-competent Arabidopsis genomic library in Agrobacterium. Biotechnology (N Y). 1991;9(10):963-7.

73. Bhosale P, Gadre RV. Optimization of carotenoid production from hyperproducing Rhodotorula glutinis mutant 32 by a factorial approach. Lett Appl Microbiol. 2001;33(1):12-6.

74. Meesters PAEP, Huijberts GNM, Eggink G. High-cell-density cultivation of the lipid accumulating yeast Cryptococcus curvatus using glycerol as a carbon source. Appl Microbiol Biotechnol. 1996;45(5):575-9.

75. Wu S, Hu C, Jin G, Zhao X, Zhao ZK. Phosphate-limitation mediated lipid production by Rhodosporidium toruloides. Bioresour Technol. 2010;101(15):6124-9.

76. Steiner S, Philippsen P. Sequence and promoter analysis of the highly expressed TEF gene of the filamentous fungus Ashbya gossypii. Mol Gen Genet. 1994:242(3):263-71.

77. Smith TL, Leong SA. Isolation and characterization of a Ustilago maydis glyceraldehyde-3-phosphate dehydrogenase-encoding gene. Gene. 1990; 93(1):111-7. 
78. Punt PJ, Dingemanse MA, Kuyvenhoven A, Soede RD, Pouwels PH, van den Hondel CA. Functional elements in the promoter region of the Aspergillus nidulans gpdA gene encoding glyceraldehyde-3-phosphate dehydrogenase. Gene. 1990;93(1):101-9.

79. Elsey D, Jameson D, Raleigh B, Cooney MJ. Fluorescent measurement of microalgal neutral lipids. J Microbiol Methods. 2007;68(3):639-42.

80. Saelices L, Youssar L, Holdermann I, Al-Babili S, Avalos J. Identification of the gene responsible for torulene cleavage in the Neurospora carotenoid pathway. Mol Gen Genomics. 2007;278(5):527-37.

81. Voelker TA, Davies HM. Alteration of the specificity and regulation of fatty acid synthesis of Escherichia coli by expression of a plant medium-chain acyl-acyl carrier protein thioesterase. J Bacteriol. 1994;176(23):7320-7.

82. Machmudah S, Goto M. Methods for extraction and analysis of carotenoids. In: Ramawat KG, Mérillon J-M, editors. Natural Products. Berlin Heidelberg: Springer; 2013. p. 3367-411.

83. Razavi SH, Blanchard F, Marc I. UV-HPLC/APCI-MS method for separation and identification of the carotenoids produced by Sporobolomyces ruberrimus H110. Iran J Chem Chem Eng. 2006;25

84. Lee LY, Gelvin SB. T-DNA binary vectors and systems. Plant Physiol. 2008; 146(2):325-32

\section{Submit your next manuscript to BioMed Central and we will help you at every step:}

- We accept pre-submission inquiries

- Our selector tool helps you to find the most relevant journal

- We provide round the clock customer support

- Convenient online submission

- Thorough peer review

- Inclusion in PubMed and all major indexing services

- Maximum visibility for your research

Submit your manuscript at www.biomedcentral.com/submit 